\title{
Seasonal grazing of locoweeds by cattle in northeastern New Mexico
}

\author{
MICHAEL H. RALPHS, DAVID GRAHAM, RUSSELL J. MOLYNEUX, AND LYNN F. \\ JAMES
}

\begin{abstract}
Authors are range scientist, USDA/ARS Poisonous Plant Lab, Logan, Ut. 84321; Union County Extension agent, Clayton N.M. 88415 ; chemist, USDA/ARS Western Regional Research Center, Albany, Calif. 94710; and research leader, USDA/ARS Poisonous Plant Lab.
\end{abstract}

\begin{abstract}
Locoweed poisoning generally occurs in early spring. We evaluated cattle grazing of woolly locoweed (Astragalus mollissimus var. mollissimus Torr.) at Gladstone, N.M., and of white locoweed (Oxytropis sericea Nutt. ex T\&G) at Capulin, N.M., through the spring and into early summer as the phenological development of warm-season grasses progressed from dormancy to rapid growth. Diets of 8 mature cows were quantified by bite count at each location. Cattle initially rejected woolly locoweed at Gladstone, even though it was the only green forage available in late March and early April. Gladstone cattle were then restricted to a small 7-ha pasture where high grazing pressure and limited feed forced them to graze woolly locoweed ( $41 \%$ of bites). When these cows returned to a larger pasture of unlimited forage availability, they continued eating woolly locoweed (23\% of bites). At Capulin, cattle with history of eating locoweed (loco-eaters) consumed more white locoweed ( $23 \%$ of bites) than cattle without a history of eating locoweed (6\% of bites) during the April graxing period. When warm-season grasses started rapid growth and locoweed matured in June, cattle ceased grazing both locoweed species.
\end{abstract}

Key Words: poisonous plants, woolly locoweed, Astragalus mollissimus var mollissimus, white locoweed, Oxytropis sericea

Locoweed poisoning of livestock is the most widespread poisonous plant problem in the western US. In northeastern New Mexico, locoweed poisoning is the greatest economic loss to the livestock industry, amounting to over $\$ 2$ million annually (Graham et al. 1991, mimeo report, Union Co. Extension). Locoweed poisoning auses neurological disturbances affecting disposition, locomotion, vision, and appetite, resulting in weight loss and emaciation. Locoweed toxicity also causes reproductive problems such as abortion, infertility, and hydrops amnii (James et al. 1981).

Locoism is a chronic poisoning and livestock must graze locoweed for several weeks before symptoms appear. Poisoning generally occurs in the winter and early spring when locoweed either remains green over mild winters, or is the first species to start rapid growth in the early spring (Marsh 1909; Peters and Sturdevent 1908; James et al. 1968, 1969; Patterson 1982).

Two major species of locoweed overlap in the high plains region of northeastern New Mexico, southwest Colorado, northwest Kansas, and the Texas and Oklahoma panhandles. Woolly or purple locoweed (Astragalus mollissimus var. mollissimus Torr.) is

\footnotetext{
The authors thank Sharla Hennigan for assistance in collecting the data and analysis of nutrients; Clayton Livestock Research Center, New Mexico State Univ., for use of facilities and equipment; Gus Warr for data analysis, and Mike Galyean and Kris Havstad for review of the manuscript.

Manuscript accepted 23 Feb. 1993.
}

a short-lived perennial whose population increases in wet years and dies in drought or from insect predation. White locoweed (Oxytropis sericea Nutt. ex T\&G) is a persistent, fairly long-lived perennial that is locally abundant on coarse soils that have a high percentage of rock (Payne 1957).

We hypothesized that livestock eat the green-growing locoweed in spring when warm-season grasses and other forage are dormant or in limited supply; and further, that animals will cease grazing locoweeds when green grass becomes abundant in the early summer. The overall objective of this study was to determine the amount of woolly and white locoweed consumed by cattle through the spring and into the early summer, as the phenological stage and nutrient quality of grasses and other forage progressed from dormancy to rapid growth.

Our second objective was to compare locoweed consumption between cows with a history of eating locoweed (loco-eaters) and cows not observed to have consumed locoweed (non-eaters). We naturally anticipated that loco-eaters would consume more locoweed than non-eaters, but the research question was to determine if loco-eaters would continue to graze locoweed as green grass became available into the early summer.

\section{Methods}

The study was conducted in western Union County in northeastern New Mexico. Cattle consumption of woolly locoweed was evaluated near Gladstone, and consumption of white locoweed was evaluated near Capulin.

\section{Locoweed Consumption as Influenced by Previous History}

Cattle differ in their propensity to graze locoweed. Some cows acquire a preference for locoweed, leading to the common observation of "habituated" or "addicted" cattle. Ranchers often separate these cows (loco-eaters) and place them in locoweed-free pastures to prevent them from becoming poisoned. Sixteen mature cows (Hereford, Angus, Charolais, and their crosses, 360 to $500 \mathrm{~kg}$ ) were purchased from a ranch with a history of locoweed problems. White locoweed was the predominant locoweed species on this ranch. Eight cows had been observed by the owner to readily graze locoweed (loco-eaters). The other 8 cows had not been observed to eat locoweed (non-eaters). We recognize that this distinction was based totally on unquantified observations of the rancher. However, dietary differences between these 2 groups (see below) bear out the validity of the selection. Four cows from each of loco-eater and non-eater groups were randomly allocated to graze woolly locoweed at Gladstone $(n=8)$ or white locoweed at Capulin $(n=8)$. All cows calved during the experiment.

Cows were gentled and diets quantified by bite count (Lehner 1987). Each animal was observed for 2 to 4, 5 -min periods during 
Table 1. Standing crop of forage classes at the 2 experiment locations during the grazing trials (kg dry matter per ha).

\begin{tabular}{|c|c|c|c|c|c|c|c|c|c|c|}
\hline Location & $\begin{array}{c}\text { Grazing } \\
\text { period }\end{array}$ & Date & $\begin{array}{l}\text { Pasture } \\
\text { size }\end{array}$ & $\begin{array}{l}\text { Warm- } \\
\text { season } \\
\text { grass }\end{array}$ & $\begin{array}{c}\text { Cool- } \\
\text { season } \\
\text { grass }\end{array}$ & Forb & Clover & Locoweed & $\begin{array}{l}\text { Snake- } \\
\text { weed }\end{array}$ & Total \\
\hline \multirow[t]{3}{*}{ Gladstone } & 1 & $3 / 29$ & $\begin{array}{l}\text { ha } \\
50\end{array}$ & $545 \pm 67$ & $62 \pm 20$ & 0 & $\begin{array}{c}-\mathrm{kg} / \mathrm{ha}= \\
13 \pm 5\end{array}$ & $125 \pm 53$ & $64 \pm 13$ & $809 \pm 71$ \\
\hline & $G^{a}$ & $\begin{array}{l}4 / 17 \\
4 / 26\end{array}$ & 7 & $\begin{array}{l}252 \pm 17 \\
182 \pm 29\end{array}$ & $\begin{array}{l}90 \pm 26 \\
64 \pm 23\end{array}$ & $\begin{array}{l}0 \\
0\end{array}$ & $\begin{array}{r}27 \pm 14 \\
5 \pm 2\end{array}$ & $\begin{array}{l}198 \pm 93 \\
183 \pm 136\end{array}$ & $\begin{array}{l}103 \pm 32 \\
153 \pm 56\end{array}$ & $\begin{array}{l}670 \pm 113 \\
592 \pm 144\end{array}$ \\
\hline & 3 & $6 / 23$ & 16 & $317 \pm 45$ & $58 \pm 16$ & $75 \pm 30$ & $56 \pm 22$ & $211 \pm 114$ & $137 \pm 36$ & $854 \pm 118$ \\
\hline \multirow[t]{2}{*}{ Capulin } & 1 & $4 / 6$ & 30 & $264 \pm 22$ & $107 \pm 33$ & $141 \pm 28$ & 0 & $45 \pm 15$ & $16 \pm 6$ & $573 \pm 45$ \\
\hline & 2 & $6 / 19$ & 30 & $405 \pm 40$ & $139 \pm 48$ & $319 \pm 43$ & 0 & $352 \pm 79$ & $62 \pm 33$ & $1277 \pm 131$ \\
\hline
\end{tabular}

${ }^{a} \mathrm{GP}=$ Grazing pressure trial.

major feeding periods each morning and evening. Number of bites taken of each plant species was counted. Species were grouped into major forage classes (warm-season grasses, cool-season grasses, clover, forbs, and the respective locoweed) and the percentage of each class in the diets was calculated.

Standing crop of forage classes was sampled at each location at the beginning and end of the study. Ten, 0.25 by $1-\mathrm{m}$ quadrats were systematically located at 20 step intervals along each of the 3 transects bisecting the pastures. Forage classes (warm-seasons grasses, cool-season grasses, forb, clover, locoweed, snakeweed) were clipped, dried in a forced air dryer at $60^{\circ} \mathrm{C}$ for 48 hours, and weighed. Mean standing crop and standard errors are presented in Table 1.

The 2 locoweed species were collected at 3 growth stages (vegetative, flower, and pod) to determine the levels of the toxic alkaloid swainsonine. Leaves, flowers, and pods of 20 to 30 plants were collected and composited into a single bulk sample. Swainsonine was measured by gas chromatography (Molyneux et al. 1989) and expressed as percentage of dry matter. Moisture and crude protein content of locoweed species and major forage species were also determined (Table 2). Plant samples were clipped, composited into

Table 2. Moisture and crude protein content ( $\%$ of dry matter) of dominant species in cattle diets during 3 growth stages of locoweed.

\begin{tabular}{|c|c|c|c|c|c|c|}
\hline \multirow[b]{2}{*}{ Location/species } & \multicolumn{3}{|c|}{ Moisture } & \multicolumn{3}{|c|}{ Crude Protein } \\
\hline & Veg & Flower & Pod & Veg & Flower & Pod \\
\hline & \multicolumn{3}{|c|}{ - . . \% \% water $-\ldots$} & \multicolumn{3}{|c|}{$\ldots$} \\
\hline Dates & $3 / 29$ & $4 / 24$ & $5 / 26$ & $3 / 29$ & $4 / 24$ & $5 / 26$ \\
\hline \multicolumn{7}{|l|}{ Gladstone } \\
\hline Woolly locoweed & 64 & 73 & 64 & 26.6 & 21.1 & 18.1 \\
\hline Clover & 71 & 70 & 56 & 25.2 & 19.3 & 20.5 \\
\hline Squirreltail & 16 & 67 & 56 & 3.9 & 5.9 & 9.1 \\
\hline Blue grama & 9 & 30 & 64 & 3.2 & 5.0 & 11.0 \\
\hline Sideoats grama & 11 & 30 & 49 & 4.8 & 5.1 & I4.6 \\
\hline 3-Awns & 9 & 27 & 31 & 3.4 & 4.9 & 5.4 \\
\hline Snakeweed & 27 & 39 & 44 & 7.9 & 8.0 & 9.0 \\
\hline Dates & $4 / 9$ & $5 / 18$ & $6 / 15$ & $4 / 9$ & $5 / 18$ & $6 / 15$ \\
\hline \multicolumn{7}{|l|}{ Capulin } \\
\hline White locoweed & 63 & 66 & 66 & 12.8 & 20.1 & 16.1 \\
\hline Forbs & 47 & 58 & 62 & 6.9 & 16.0 & 14.0 \\
\hline Western wheat & 41 & 48 & 49 & 2.5 & 10.1 & 11.1 \\
\hline Blue grama & 10 & 41 & 34 & 3.5 & 6.7 & 9.7 \\
\hline Sideoats grama & 14 & 36 & 48 & 2.4 & 8.6 & 11.1 \\
\hline 3-Awns & 16 & 40 & 36 & 4.4 & 7.5 & 8.0 \\
\hline Snakeweed & 50 & 43 & 40 & 7.4 & 12.3 & 9.0 \\
\hline
\end{tabular}

a single bulk sample, weighed on site, then dried at $60^{\circ} \mathrm{C}$ for 48 hours to determine moisture content. Crude protein was determined by a micro-kjeldahl tecator digestion system and expressed on a dry matter basis.

\section{Woolly Locoweed}

The study was conducted at Gladstone, N.M., on a 50-ha field that had been farmed until 1963, then seeded to blue grama [Bouteloua gracilis (H.B.K.) Lag. ex Steudel], sideoats grama [B. curtipendula (Michx. Torr.], and yellow sweet clover [Melilotus officinalis (L.) Pallas]. Some squirreltail [Elymus elymoides (Raf.) Swezey], three-awns [Aristida spp.], and broom snakeweed [Gutierrezia sarothrae (Pursh) Britt. \& Rusby] came back naturally. A population outbreak of woolly locoweed occurred throughout this area in the fall, 1989, and a dense infestation remained in the spring, 1991.

Woolly locoweed consumption was evaluated in 3 grazing periods corresponding to the vegetative, flower, and pod stage of development. Treatment groups consisted of loco-eaters and noneaters described above. Diets were determined using bite counts as previously described.

\section{Period 1-28 March to 2 April}

Woolly locoweed was green and rapidly growing, but all other vegetation was dormant. Cows were allowed to graze freely in the 50-ha pasture with unlimited forage availability. A blizzard occurred during this period and we were able to measure selection patterns under extreme weather conditions.

\section{Period 2-27 April to 5 May}

Woolly locoweed was in the flower stage and the cool-season grasses and clover were growing rapidly. Warm-season grasses were starting to show green leaves, but there was little active growth.

\section{Period 3-31 May to 23 June}

Woolly locoweed was in the pod stage and warm-season grasses were beginning to grow rapidly. Cows were restricted to a 16-ha pasture to allow sufficient feed for the trial but not present an unlimited supply. Diets were sampled on alternate days.

\section{Grazing Pressure Trial-17 to 26 April.}

The cows did not graze woolly locoweed in Period 1, even though it was the only green forage available, and the only feed protruding above the snow for a period of time. We initiated a grazing pressure trial between periods 1 and 2 to restrict forage availability and determine if the cows would start grazing woolly locoweed as other forage became limited. Vegetation standing crop was sampled at the beginning and end of this trial. Based on the initial standing crop, a 7-ha pasture was fenced with enough feed to last for only 10 days. Grazing pressure would increase as forage declined over time. Diets were quantified by bite count as described above.

\section{White Locoweed}

This study was conducted $3 \mathrm{~km}$ north of Capulin. The site was on 
a section of the ranch from which the cattle were purchased, so the cows were familiar with the site. The 30 -ha site was a combination of abandoned farmland that had been reseeded, and native range among volcanic basalt rock outcroppings. Soils were silty clay loam. Major warm-season grasses consisted of blue grama, sideoats grama and little bluestem [Schizachyrium scoparium (Michx.) Nash]. Western wheatgrass [Elymus smithii (Rybd.) Gould] was the dominant cool-season grass. White locoweed was the dominant forb.

Cattle consumption of white locoweed and associated forage classes were quantified on 2 periods. Treatment groups consisted of loco-eaters and non-eaters described above. Diets were quantified by bite count as described above and were sampled on alternate days.

\section{Period 1-10 to 29 April.}

White locoweed was actively growing in the vegetative stage. Warm-season grasses were dormant, and cool-season grasses were green and beginning to grow.

\section{Period 2-30 May to 23 June.}

White locoweed was in the pod stage. Cool-season grasses were starting to form heads, and warm-season grasses and forbs were beginning rapid growth.

\section{Data Analysis}

Data from the 2 trials were analyzed separately. There was no attempt to compare consumption of the 2 locoweed species. Data from each of the 2 trials were analyzed by analysis of variance (ANOVA) in a split-plot repeated measures design (Gill 1978). Treatment group (loco-eaters vs. non-eaters) was the main plot and period was the split plot in time. Each cow was considered an experimental unit. The population in these trials was limited to the experimental animals at each location, and the conclusions are not extrapolated beyond this study. The percentage data of forage classes in diets were transformed by arcsin for the analysis, but the nontransformed means are presented in the tables. Where differences occurred, means were separated by LSD $(P<0.05)$.

The grazing pressure trial at Gladstone was also analyzed by a split-plot repeated measures model. Treatment group (loco-eaters vs. non-eaters) was the main plot and days of the trial was the split-plot in time. Days of the 10-day trial represented increasing grazing pressure as the availability of forage declined. Orthoginal contrasts were used to describe woolly locoweed consumption as grazing pressure increased over the days of the trial.

\section{Results and Discussion}

\section{Woolly Locoweed-Gladstone}

There was no difference in woolly locoweed consumption between loco-eaters and non-eaters at Gladstone in any of the periods or grazing pressure trial $(P>0.05)$. The propensity to eat white locoweed, which was the basis for designating loco-eaters, did not generalize to woolly locoweed. Woolly locoweed consumption differed between the 3 grazing periods $(P<0.01)$.

\section{Period 1.}

Woolly locoweed was not consumed in the first period when forage was not limited. It was 10 to $15-\mathrm{cm}$ high and comprised $15 \%$ of the standing crop (Table 1). It was the only green feed available at the beginning of the trial. It was highly succulent (64\% moisture) and contained $26 \%$ crude protein (Table 2 ). Warm-season grasses (blue and sideoats grama and three-awns) dominated the diets (Table 3), although they were dormant, dry, and very low in crude protein.

Table 3. Forage classes in cattle diets (percent of bites) at Gladstone during grazing periods (means \pm standard error, $n=8$ ).

\begin{tabular}{lccccc}
\hline \hline $\begin{array}{l}\text { Graz- } \\
\text { ing } \\
\text { period }\end{array}$ & Dates & $\begin{array}{l}\text { Woolly } \\
\text { loco- } \\
\text { weed }\end{array}$ & Clover & $\begin{array}{l}\text { Cool- } \\
\text { season } \\
\text { grass }\end{array}$ & $\begin{array}{c}\text { Warm- } \\
\text { season } \\
\text { grass }\end{array}$ \\
\hline & & & & & \\
1 & $3 / 28$ to $4 / 2$ & $0^{\mathrm{b}}$ & $24^{\mathrm{b}} \pm 0.9$ & $18^{\mathrm{a}} \pm 1.6$ & $56^{\mathrm{a}} \pm 1.5$ \\
2 & $4 / 27$ to $5 / 5$ & $23^{\mathrm{a}} \pm 3.2$ & $39^{\mathrm{a}} \pm 3.0$ & $5^{\mathrm{b}} \pm 0.9$ & $30^{\mathrm{c}} \pm 2.2$ \\
3 & $5 / 31$ to $6 / 23$ & $5^{\mathrm{b}} \pm 2.6$ & $44^{\mathrm{a}} \pm 5.6$ & $0^{\mathrm{c}}$ & $47^{\mathrm{b}} \pm 2.9$ \\
\hline
\end{tabular}

Means within forage classed not followed by the same letter differ significantly $(P \leq .05)$.

The first 2 days of the period were mild and cattle selected mostly dry, warm-season grasses. A blizzard started on the morning of day 3, but cleared up by afternoon. As the weather moderated, snow melted first around the taller growing woolly locoweed plants. It was the only feed available above the snow for 1.5 days. Nevertheless, cattle continued to reject woolly locoweed and dug through the snow to select dry grasses. By the end of the period, the cool-season grasses (predominately squirreltail) and clover were growing rapidly. Although they were limited in quantity, these cool-season species comprised 18 and $24 \%$ of cattle diets, respectively (Table 3 ). Although diet sampling ended on 2 April, the cows grazed in this pasture until the grazing pressure trial began on 27 April, and were still not eating woolly locoweed at the beginning of the grazing pressure trial.

Cattle rejected woolly locoweed under extreme conditions when it was the only green feed, and when it was the only forage above the snow. This finding agrees with the assessment by Marsh (1909) that cattle will not readily graze woolly locoweed.

\section{Grazing Pressure Trial}

Woolly locoweed was not consumed in the first grazing period, even under extreme grazing conditions discussed below. Therefore, we initiated a grazing pressure trial between periods 1 and 2 to determine if increasing grazing pressure on diminishing forage supply would force cattle to start grazing woolly locoweed. The results of this trial influenced subsequent consumption of woolly locoweed in the remaining grazing periods.

There was a difference in diets over the days of the trial as grazing pressure increased $(P<0.01)$. Woolly locoweed was not consumed during the first 3 days of the trial (Fig. 1). Clover comprised 25 to $30 \%$ of diets and warm-season grasses averaged $60 \%$ at the beginning. As feed became limited and cattle ran out of

Table 4. Forage classes in cattle diets (percent of bites) at Capulin during 2 grazing periods (means \pm standard error, $n=4)$.

\begin{tabular}{|c|c|c|c|c|c|c|}
\hline Grazing period & Dates & Group & White locoweed & Forbs & $\begin{array}{c}\text { Cool-season } \\
\text { grass }\end{array}$ & $\begin{array}{c}\text { Warm-season } \\
\text { grass }\end{array}$ \\
\hline 1 & $4 / 10$ to 29 & $\begin{array}{l}\text { Loco-eaters } \\
\text { Non-eaters }\end{array}$ & $\begin{array}{r}23^{\mathrm{a}} \pm 3.4 \\
6^{\mathrm{b}} \pm 1.4\end{array}$ & $\begin{array}{l}6^{a} \pm 0.6 \\
8^{a} \pm 1.1\end{array}$ & $\begin{array}{l}26^{\mathrm{a}} \pm 3.4 \\
27^{\mathrm{a}} \pm 3.0\end{array}$ & $\begin{array}{l}44^{\mathrm{a}} \pm 3.1 \\
57^{\mathrm{b}} \pm 3.2\end{array}$ \\
\hline 2 & $5 / 30$ to $6 / 23$ & $\begin{array}{l}\text { Loco-eaters } \\
\text { Non-eaters }\end{array}$ & $\begin{array}{l}2^{\mathrm{a}} \pm 1.4 \\
0^{\mathrm{a}} \pm 0.2\end{array}$ & $\begin{array}{l}40^{\mathrm{a}} \pm 2.8 \\
44^{\mathrm{a}} \pm 2.5\end{array}$ & $\begin{array}{l}13^{\mathrm{a}} \pm 3.1 \\
13^{\mathrm{a}} \pm 2.7\end{array}$ & $\begin{array}{l}44^{\mathrm{a}} \pm 3.9 \\
42^{\mathrm{a}} \pm 3.2\end{array}$ \\
\hline
\end{tabular}

"heans within grazing periods and forage classes not followed by the same letter differ significantly $(P<.05)$. 


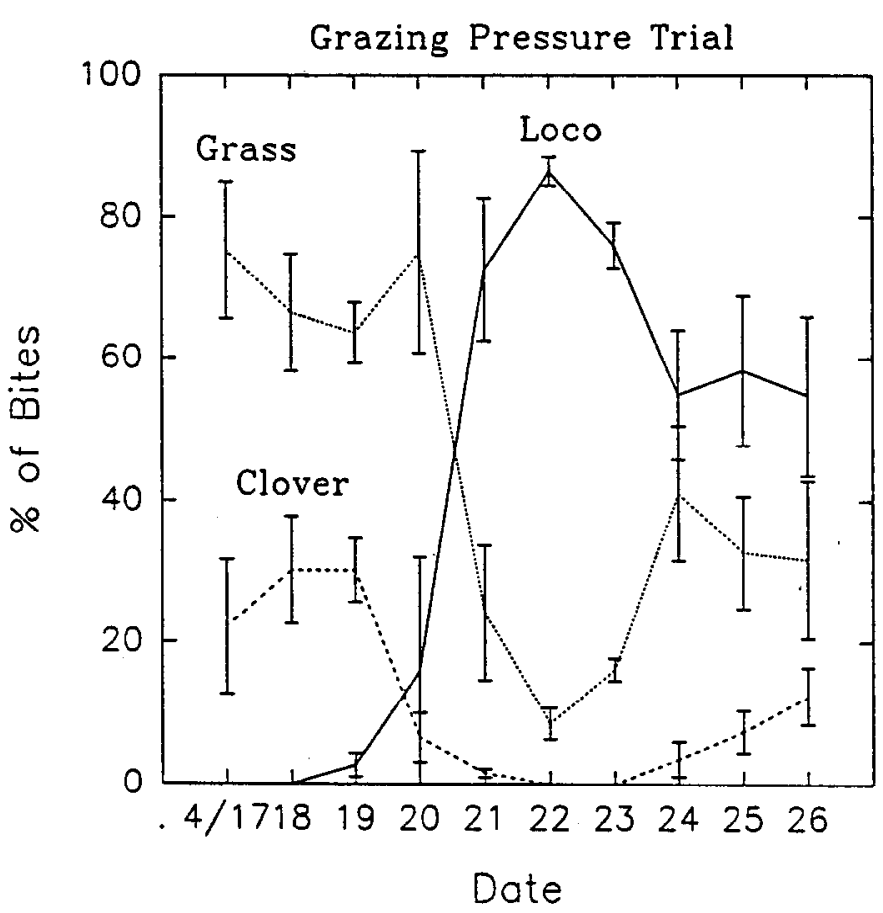

Fig. 1. Forage classes in diets of Gladstone cattle during the grazing pressure trial. Cattle were placed in a small, 7-ha pasture where forage became inadequate by the end of the trial. Error bars are standard errors.

clover, they switched to locoweed. Orthoginal contrasts showed that locoweed consumption followed a cubic response $(P<0.01)$. Woolly locoweed was not consumed at the beginning of the trial; it increased to $85 \%$ of the diets at mid trial, and then leveled off at about $55 \%$.

Grazing pressure was totally confounded with days in this trial. Over time, there may have been chemical changes in woolly locoweed that increased its acceptability. However, swainsonine content of woolly locoweed reached its peak during this period (see discussion below), and crude protein levels were declining (Table 2). High alkaloid levels have a negative relationship with palatability (reviewed by Ralphs and Olson 1987). Therefore, we interpret this data to indicate that as cattle ran short of other feed, they started grazing woolly locoweed.

\section{Period 2.}

Once cattle were forced to start eating woolly locoweed in the grazing pressure trial, they continued to eat it in period 2, even though clover and cool-season grasses were abundant in the large 50-ha pasture. Locoweed consumption during this period was highest in the study, averaging $23 \%$ of bites (Table 3 ). The cows were selective in the woolly locoweed plants they chose to eat. They would sniff and reject some plants, but would completely devour others. Clover was selected for $38 \%$ of diets and warm season grasses for $31 \%$.

\section{Period 3}

Cows reduced woolly locoweed consumption over time, and ceased eating it entirely by the end of this trial in June. Warmseason grasses were growing rapidly and woolly locoweed was mature. Patches of woolly locoweed also were beginning to die from insect predation. Clover and warm-season grasses dominated diets, comprising 45 and 44\%, respectively (Table 3).

Cattle consumption of forage apparently kept up with new growth during this period. Standing crop did not increase during this period of rapid growth at Gladstone as it did at Capulin (Table 1). This was due to the reduced pasture size (16 ha). Even though grazing pressure was a factor in this period at Gladstone, cattle did not graze very much woolly locoweed.

\section{White Locoweed}

There was a period-by-group interaction $(P<0.05)$ in consumption of white locoweed and warm-season grasses. In period 1, loco-eaters consumed white locoweed for $23 \%$ of their diets, compared to only $6 \%$ of the non-eaters (Table 4). Locoweed was green and actively growing, having a crude protein content of $13 \%$ (Table 2). Cool-season grasses, predominantly western wheatgrass, comprised $26 \%$ of the diets, and dormant warm-season grasses comprised $44-57 \%$ of the diets (Table 4 ).

There was very little white locoweed consumption in June during Period 2 (Table 4). There was no difference between loco-eaters and non-eaters in any forage class consumed in this period. Cattle with a propensity to graze white locoweed (the basis of the locoeater designation) did not continue to select white locoweed when warm-season grasses became plentiful. Warm-season grasses and forbs dominated cattle diets.

Standing crop of all forage classes increased by the end of the trial (Table 1), suggesting that increased availability and improved nutrient quality of grasses and forbs influenced cattle to stop grazing white locoweed. Maturity of locoweed also may have contributed to cessation of grazing white locoweed.

\section{Swainsonine in Locoweeds}

Swainsonine content of woolly locoweed was 0.5 to 9 times higher than in white locoweed (Table 5). The higher concentration of swainsonine in woolly locoweed may have contributed to its initial rejection. Ralphs and Molyneux (1989) concluded that

Table 5. Swainsonine concentration in locoweed species and plant parts (percent of dry matter).

\begin{tabular}{|c|c|c|c|c|}
\hline \multirow[b]{2}{*}{ Species } & \multirow[b]{2}{*}{ Plant part } & \multicolumn{3}{|c|}{ Growth stage } \\
\hline & & Vegetative & Flower & Pod \\
\hline $\begin{array}{l}\text { Woolly } \\
\text { locoweed }\end{array}$ & $\begin{array}{l}\text { Leaf } \\
\text { Flower } \\
\text { Pod }\end{array}$ & $\begin{array}{c}.09 \\
- \\
-\end{array}$ & $\begin{array}{c}-. \%-- \\
.18 \\
.28 \\
-\end{array}$ & $\frac{19}{15}$ \\
\hline $\begin{array}{l}\text { White } \\
\text { locoweed }\end{array}$ & $\begin{array}{l}\text { Leaf } \\
\text { Flower } \\
\text { Pod }\end{array}$ & $\begin{array}{l}.01 \\
- \\
-\end{array}$ & $\begin{array}{l}.08 \\
.09 \\
-\end{array}$ & $\frac{.11}{.10}$ \\
\hline
\end{tabular}

swainsonine concentration in white locoweed and spotted locoweed (A. lentiginosus var. wahweapensis) ( 0.02 to $0.1 \%$ of dry weight) did not affect acceptability of locoweeds. However, quinolizidine alkaloids of Lupinus and indolizidine alkaloids of Phalaris have strong negative correlations with palatability; as the alkaloid concentration of these plants increase, palatability declines (reviewed by Ralphs and Olsen 1987). The higher concentration of swainsonine in woolly locoweed from our study (0.09 to $0.28 \%)$ may be detectable by cattle and may have contributed to its initial rejection. Another possible explanation for the initial rejection of woolly locoweed could be its dense pubescence. Once cattle started grazing woolly locoweed, it was accepted readily.

\section{Conclusions and Recommendations}

Gladstone cattle initially rejected woolly locoweed even under extreme grazing conditions. However, once they were forced to start eating it, due to increasing grazing pressure on other forage, they continued to consume woolly locoweed, even though green feed was plentiful. Marsh (1909) reported that woolly locoweed was less palatable than white locoweed, and cattle generally refused it. 
Cattle may be able to graze range infested with woolly locoweed in the spring if other forage is abundant. They should be watched closely to see if any start eating woolly locoweed, and those removed that do. Shortage of feed with its attendant high grazing pressure, social facilitation (Ralphs et al. 1993), or supplementing with alfalfa hay or cubes (David Graham, personal observations) may compel cattle to start grazing woolly locoweed.

Capulin cattle grazed white locoweed in the spring when it was green and succulent and the warm-season grasses were dormant. Cows having a history of eating locoweed (loco-eaters) consumed more white locoweed at Capulin than did non-eaters in the April grazing period. The practice of ranchers watching for loco-eaters and removing them from locoweed pastures is a practical means of reducing locoweed poisoning.

All cows in this study grazed the respective locoweed species to greater or lesser extent during the April and May grazing periods. All cows showed varying signs of locoism (i.e., depression and solitary behavior). Once growth of warm-season grasses started and green grass became abundant, all cattle, including the locoeaters, ceased grazing both white and woolly locoweed.

Results from this study agree with others (Marsh 1909; Peters and Sturdevent 1908; James et al. 1968, 1969; Patterson 1982) that spring is a critical time for locoweed consumption and subsequent poisoning. We speculate that this is because locoweed is green and actively growing and warm-season grasses and other forage is still dormant. Once green grass becomes abundant, locoweed consumption is no longer a problem.

The surest means to prevent locoweed poisoning is to create or maintain a locoweed-free pasture for spring grazing. Many locoweed species are locally endemic or restricted to certain soils or habitats. Sites with no or light locoweed infestations could be reserved for spring grazing. Locoweeds can also be controlled by rangeland herbicides (Ralphs and Ueckert 1988), but periodic spraying may be necessary because of the large number of viable seeds that remain in the soil.

\section{Literature Cited}

Gill, J.L. 1978. Design and analysis of experiments in the animal and medical sciences. p. 203-214. Iowa State Univ. Press, Ames.

James, L.F., K.L. Bennett, K.G. Parker, R.F. Keeler, W. Binns, and B. Lindsay. 1968. Loco plant poisoning in sheep. J. Range Manage. $21: 360-365$.

James, L.F., W.J. Hartley, and K.R. Van Kampen. 1981. Syndromes of Astragalus poisoning in livestock. J. Anim. Vet. Med. Assoc. 178: 146-150.

James, L.F., K.R. Van Kampen, and G.R. Stokes. 1969. Locoweed (Astragalus lentiginosus) poisoning in cattle and horses. J. Amer. Med. Assoc. 155:525-530.

Lehner, P.N. 1987. Design and execution of animal behavior research: an overview. J. Anim. Sci. 65:1213-1219.

Marsh, C.D. 1909. The loco-weed disease of the plains. USDA Bull. 112.

Molyneux, R.J., L.F. James, K.E. Panter, and M.H. Ralphs. 1989. The occurrence and detection of swainsonine in locoweeds. p. 100-117. In. A.D. Elbein, R.J. Molyneux, and C.D. Warren (eds.), Swainsonine and related glycosidase inhibitors. Iowa State Univ. Press, Ames, Iowa.

Patterson, P.E. 1982. Loco, la yerba mala. Rangelands 4:147-148.

Payne, G.F. 1957. Certain aspects of the ecology and life history of the poisonous plant, white pointloco Oxytropis sericea. Diss. Texas A\&M Univ., College Station.

Peters, A.T., and L.B. Sturdevent. 1908. Locoweed poisoning in horses. Nebraska Agr. Exp. Sta. Annu. Rep. 21:74-107.

Ralphs, M.H., D. Graham, and L.F. James. 1993. Social facilitation and influences cattle to graze locoweed. J. Range Manage. (in press).

Ralphs, M.H., and R.J. Molyneux. 1989. Livestock grazing locoweed and the influence of swainsonine on locoweed palatability and habituation. p. 39-49, In: L.F. James, A.D. Elbein, R.J. Molyneux, and C.D. Warren (eds.), Swainsonine and related glycosidase inhibitors. Iowa State Univ. Press, Ames.

Ralphs, M.H., and J.D. Olsen. 1987. Alkaloids and palatability of poisonous plants. p. 78-83. In: F.D. Provenza, J.T. Flinders, and E.D. McArthur (eds.) Proc.-Symp. on Plant-Herbivore Interactions. USDA Forest Serv. Gen. Tech. Rep. INT-222.

Ralphs, M.H., and D.N. Ueckert. 1988. Herbicide control of locoweeds: A review. Weed Tech. 2:460-465. 